\title{
Factors That Influence Financial Behavior Among Accounting Students in Bali
}

\author{
Nyoman Trisna Herawati ${ }^{1}$, I Made Candiasa ${ }^{2}$, I Ketut Yadnyana ${ }^{3}$ \& Naswan Suharsono ${ }^{1}$ \\ ${ }^{1}$ Faculty of Economics, Ganesha University of Education, Singaraja, Bali, Indonesia \\ ${ }^{2}$ Postgraduate Program, Ganesha University of Education, Singaraja, Bali, Indonesia \\ ${ }^{3}$ Faculty of Economics, Udayana University, Denpasar, Bali, Indonesia \\ Correspondence: Nyoman Trisna Herawati, Faculty of Economics, Ganesha Univesity of Education, Singaraja, Bali, \\ Indonesia.
}

Received: April 16, 2018

Accepted: May 7, 2018

Online Published: May 15, 2018

doi:10.5430/ijba.v9n3p30

URL: https://doi.org/10.5430/ijba.v9n3p30

\begin{abstract}
This study was aimed at analyzing factors that influence financial behavior among accounting students in Bali. This study used the quantitative approach through distributing questionnaires and a financial literacy test. The sample was selected through the multistage random sampling technique with the sample size of 518 respondents. The data were analyzed by using multiple regression analysis. The results of the study showed that there is a positive and significant effect of financial literacy, financial self efficacy, social economic status on financial behavior. Social economic status has the highest contribution. The finding shows that the independent variables in this study have an effect on financial behavior. As the consequence, they can be used as references to develop other variables that are related to students' financial behavior.
\end{abstract}

Keywords: financial literacy, financial self efficacy, social economic status, financial behavior

\section{Introduction}

The growth of global economy today brings the effect of change into the social financial system. This can be seen from the effect of complexity and use of technology on financial products and services. For example, a wide access to loan disbursement and financial service product.If this is not treated with a good financial behavior, one can be easily trapped in an unfavorable economic situation. Financial behavior can be related to personal financial management. Personal financial management is one of the applications of the concept of financial management atthe individual level that comprises activities for financial planning, management, and control. Planning activity consists of the activity to plan, what a received income allocated to be used for. Management is the activity for managing finance efficiently, while controlling is the activity for evaluating whether the financial management has been in accordance with what was planned/ budgeted. A healthy financial behavior can be seen from the attitude of a person in managing the in-coming and out-going of money, managing loans and investments (Layli, N., 2013).

A good financial behavior development in students calls for a special attention because the financial behavior aspect has a significant effect on their life after graduation from a university. For the students who live far away from their parents, for the first time they will be faced with the choice of monthly financial management by themselves. On the other hand, consumptive behavior among the students is very high along with the rampant of online business that is developing today. A result of study shows that teenagers in Bali agedfor 17 to 25 have thefirst rank (44\%) in thebuying ofthings through online, while the smallest percentage is $11 \%$ obtained from respondents aged $40-55$ years old. Based on the data it can be concluded that online market depends very much on the consumptive culture of the netizens of relatively young age or teenagers (Dwipayani and Rahyuda, I.K, 2015). Besides, today the government has issued "YUK NABUNG SAHAM" program to increase the inclusion of social finance especially in investing in capital market. This program gives the chance to everybody including students to have share portfolios although in a limited financial amount (www.idx.co.id, 2018). Another program is the government initiative to disburse loans for students to help poor students to be able to study at the university (Kompas.com, 2018). The programs need financial knowledge to make the students able to understand the benefits and risks of every decision to be made. 
Financial behavior may be influenced by an individual's financial literacy. Financial literacy can be interpreted as financial knowledge with the purpose of acquiring wealth. An individual with good financial literacy will influence his or her financial behavior toward a positive direction, such as the payment of a bill on time, having savings and investment, and ability to managecredit cards wisely (Lusardi, A, Olivia, M \&CurtoVilsa, 2010). Financial literacy has a significant effect on financial behavior (Danes and Haberman, 2007; Laily, 2014, Susanti, 2013). Results of Chen and Volpe's study (1998) showed that students with a lower financial literacy tend to choose a wrong financial desicion than those with a higher financial literacy. The other research findings (Robb andWodyard, 2011) showed that a good financial behavior subjectively and objectively influence higher level of financial literacy significantly. Whether an individual's financial management is wise or not is closely related to the individual's ability and knowledge of concepts in financial liteacy. Hence, financial literacy influences almost all aspects related to planning and expenditure including his or her financial behavior.

Financial literacy and self efficacy are two factos that play a part in affecting how his or her financial behavior is. Self Efficacy can be understood as an individual's belief about his or her ability to organize and do a series of actions deemed necessary to reach something desired. In its relation to his or her financial behavior, self- efficacy is related to financial self efficacy which can be defined as a belief in one's ability to change financial behavior toward a better direction (Danes \& Haberman, 2007). Self Efficacy or self confidence is a key component in Bandura's social cognitive theory that characterizes an individual's self confidencein his or her ability to be successful in doing a task. An individual's belief in his or her own ability can help in determining results expected, since an individual has confidence in anticipating all actions to reach a desired goal. A confident person sees difficult tasks as a challenge to meet rather than as a threat to be avoided. He or she has a stronger interest and a deep engrossment in an activity done, writing a challenging objective, and has a strong commitment in achieving the desired goal (Pajares, 2002). The results of studies showed that attitude in managing funds get a higher mean score than self confidence in making good financial decisions. This indicates that an individual's self efficacy affects his or her financial behavior in the future. Thus, financial self efficacy helps the students to act and change his or her finacial behavior toward a better direction (Danes and Haberman 2007). In addition, the result of the studies showed that students' financial self efficacy has a significant and negative effect on their credit card loan behavior. This indicates that the students with a high financial self efficacy will derive an unhealty or irrational behavior toward loan (Kennedy, P. Brian, 2013). Similarly, a study (Hecman, Stuart; Lim, HanNa; and Montalto, Catherin, 2014) showed that students with a high financial self efficacy and greater financial optimism about future are significantly less likely to report financial stress. This indicates that financial self efficacy will influence students' financial behavior toward a bettter one.

In addition to financial literacy and financial self efficacy, family's social condition also play a role in the students' financial behavior. Students with parents who have a high social status have opportunities to develop various skills, and the reverse. Different in social economic status level will have an effect on the emergence of difference in perception toward a physical object or behavioral object, which finally forms a different attitude. Positive perception of the characteristics or qualities of objects will form positive attitude too (Ahmadi, 2007). The result of studies showed that financial knowledge, financial attitude, and financial behavior differ from one student to another with high, medium, or low social economic status (Gutter, M; Copur, Z; \& Garrison, S, 2009). It means that students with high social economic status will also have a high level of knowledge, attitude, and behavior. Financial attitudes such as open to information, has a high appresiation of the importance of financial management, not impulsivein consumption, has an orientation toward the future and has a full responsibility is corelated with good financial behavior. Similarly, a study (Albeerdy, Mohammad, I. \& Behrooz Gharleghi, 2015) showed that parents are important socialization agents in family financial education. This study indicates that parents' social economic status can have a positive impact on the children's financial behavior development.

Based on the background above this study investigated the financial behavior of the students of the department of accounting who were influenced by the variables of financial literacy, financial self efficacy, and parent's social economic status. The department of accounting which is involved much in financial teaching turns up to have poor literacy level so that this needs to be investigated further (Herawati, N.T, 2017). Based on the explanation in the background above, this study was aimed:

1. To find out the effect of financial literacy on financial behavior among accounting students.

2. To find out the effect of financial self efficacy on the financial behavior among accounting students.

3. To find out the effect of social economic status on the financial behavior of the students of accounting departments. 


\section{Literary Review}

\subsection{Effect of Financial Literacy on Financial Behavior}

Financial literacy is a new term and we may be unfamiliar with it. On the other hand, this knowledge is often applied in daily life, consiously or unconsiously. Literacy is not limited to language, but it is aplicable to knowledge about certain topic or kind of knowledge. People who are good at a skill, are able to understand and evaluate issues related to that skilll and awear of the potential consiquence of this are called well literate. Financial literacy can be defined as an individual ability to obtain, understand, and evaluate information which is relevant to the decision making by understanding of the financial consiquence that occur as the effect of the development in the complexcity of the global finance (Danes \&Haberman, 2007). In the era of advanced technology today, individuals are involved in complex financial decision making. If we are not wise in understanding this phenomenon we will be trap in financial problem. That is why financial literacy is becoming important, since individual have responsibilities for their financial security in their life.

Financial literacy has a significant effect on financial behavior. A person who has a low financial literacy usually has financial problems which among others thing having loose debt that can not be repaid, having no social security, and adequate pension program. Thus, financial literacy is in important component in financial good financial behavior for today and the future. This is in line with the finding Mitusibishi Research Institute (2002) that state various factor that influence individual success at work. The factors are: (1) the financial in ability contributes by $10 \%$ to and individual success, (2) expertice / competence in his or her field (20\%) to a person success, (3) networking contribute to a person success (30\%), and soft skill (40\%) contributes to a persons success. This becomes interesting that today financial literacy is needed badly to support one's success Gutter (2008) showd that financial knowledge is the main predictor in forming financial behavior. This is in line with Susanti (2013) that financial litearcy has a significant effect on students'financial behavior.

\subsection{The Effect of Financial Self-efficacy on Financial Behavior}

Financial literacy and self efficacy are to things which make changes in financial behavior (Danes \&Huberman, 2007). Self efficacy is one's beliefes about the ability that he or she has to be able to organize and do as serries of action deemd necessary to achieve a desired result. In this studyself efficacy was related to the students' financial self efficacy, i.e., belief in self ability to changes financial behavior to a better direction.

Today financial education is not the only element that can change individual financial behavior toward a better direction. "A major factor influencing consumer behavior is the feeling of self-efficacy which is having the confidence in one's ability to deal with a situation without being overwhelmed" (Lown, Jean. M. 2011). This indicates that self confidence about financial ability that one owns influences how one behaves. Self efficacy influences workers' attitude and behavior in reaching their goal, high commitment, and good performance, which also can be applied in financial behavior. There has no a standard instrument which can measure financial self efficacy. In this study financial self efficacy dimension was developed by adapting self efficacy dimensions in general, i.e., level (magnitude), strength and generality (Bandura, 1997). First, level (magnitude), it is the financial self efficacy dimensionscale seen from the level of task difficulty felt by an individual. This component has an implication in selecting a behavior which will be used based on the level of difficulty. Individuals will attempt to do a certain task which he or she perceives can be done and he or she will avoid situations and behaviors which he or she perceives difficult.Secondly, generality dimension. This dimension is a financial self efficacy assessment scale which measures to what extent an individual believes in his or her ability in various task situations, starting from the activity which can be usually done to the activity which has not been done yet. This indicates to what extent a person is convinced of his or her ability in performing various different tasks, from specific tasks to groups of different tasks.The third dimension is strength. This dimension implies self confidence a person has which is realized in performing a certain task. Individuals who become convinced very much on their self abilities williketasks which are full of challenges better and have a strong steadiness in ability to perform the tasks and keep on in their effort althoughthere are many difficulties and obstacles. These three dimensions will be related with one self confidence in managingfinance whichis called financial self efficacy.

The results ofstudies showed that attitude (self confidence/belief) in managing finance got a higher score than self confidence in making appropriate financial decision (Danes \& Haberman, 2007). This indicates that one self efficacy has more influence on his or her financial behavior in the future. Thus, financial self efficacy helps students to act and change financial behavior toward a better direction. According to the study, Keneedy, P. Brian (2013) analyzed the effect of theory of planned behavior (TTB) on behavior in credit cardloan. The study reffered to self efficacy, i.e., an individual's belief in his or her ability to perform a task at a certain level in his or her performance. The result 
showed that financial self efficacy has a negative impact on the students' behavior towardcredit card.This indicates that students with a high financial efficacy will reduce unhealthy or irrational behavior. Thus, in this case, it can be concluded that financial self efficacy has an effect on financial behavior. The higher a person financial self efficacy the better the individual financial behavior.

\subsection{The Effect of Social Economic Status on Financial Behavior}

The formation of a good behavior in children needs a special attention since the financial behavior influences the future life. The financial behavior formed in childhood in an addition to the environment factors at school and in the child himself or herself is also influenced very much by the family's social economic status. Social class refers to a big group of people with ratings which are close in terms of wealth, power, and prestige. The three elements separate people into different life styles, give them ability to lead a different life, and provides them different ways to look at himself or herself and the world (Weber in Henslin, M. James 2006). The measurements used to group people into social classes are limitless and relative, so that one group of people cannot be compared with another. Every society has a different set of criteria to measure social status. Thus, the criteria in measuring social economic status basically depend on the values held by the members of the society themselves. The main dimensions of social class are wealth, income, power, and prestige.Wealth is the value of an individual owership in various forms of assets, such as buildings, land, animal, car, share, business obligation, and bank account. Incomeis the money obtained from businesses, wages, rents, interests or royalties. Power refers to those who make big decisions in the society. Job and prertige are the outcomes of education. Low occupations will lead to a lower prestige (Henslin, M. James 2006).

The results of the studies showed that social economy factor has a significant influence on attitude. Someone's social economic and demografic conditions have an influence on his or her attitude as part of psycological variable construct (Widayati. I, 2011). The financial literacy aspect of this attitude can be related to financial behavior, since financial attitude can be defined as an individual's psyichological characteristic which is related to personal financial problem. The results of the studies showed that parents' income has a significant effect on financial behavior shown with the ownership of credit management, savings and invesments and planning thepension financial schemes (De BassaScheresberg, Carlo, 2013). This study indicates that parents' social economic status can have a positive effect on the children's financial behavior development.

\subsection{Financial Behavior}

Financial behavior can be related to the concept of financial management at individual level, i.e., planning, management, and controlling. Individual financial behavior can be related to the task of a financial manager in a company. The main functions of financial manager in a company are to plan, look for and use funds to maximize the value of the company, or in other words, the activity is related to the decision about the selection of resources and financial allocation. Generally, the activities of financial manager are: (1) to predict and plan funds, (2) to make decisions on capitalization, investment, and growth (3) to control. In planning funds, the financial manager has to be able to plan what activities can be done in the future. For this reason, he or she has to write financial budgeting to do the activities viewed from the capitalization aspect. The financial manager is required to be able to collect funds needed, both in a short time and long time through value funding alternatives through investment, loan and equity. In performing control, the manager is required tobe able to controlthe company financial activity so that it can run in accordance with the financial bugdet that has been planned. Based on the explanation above it can be concluded that financial behavior is an activity of financial management at individual level consisting ofplanning, management, and controlling funds (Kasmir 2010).

Financial behavior in this study was students' behavior in planning, managing and controlling financial resources, in this case pocket money from the parents or other people give sucs as scholarship. The aspect used to describe the students' financial behavior is based on Danes \&Haberman opinions (2007) by adapting to students financial system in Indonesia. This adaption was made at the aspect of financial acquisition (the ways money was acquired). In this case it is assumed that students in Indonesia in general are not yet familiar with the activity of working while studying. For this reason this aspect can be ommited and is adapted to the students' behavior in writing a good financial plan. In addition, related to indicators of using loans by paying on time will be ommited, because in Indonesia the holders of credit cards are still limited to the ones withself income and not for students. The aspect of financial behavior in students will be related to four important aspects of good financial management which include: (1) the behavior in writing financial planning/budgeting, (2) the behavior of savings and or investing, (3) the behavior of using or expending money, and (3) the behavior of evaluating, which, in this case, is related to communicating financial problems with family and the evaluation of the use of the budget. 


\section{Methods}

\subsection{Research Framework}

This study used the quantitative paradigm that tests theories by measuring research variables and doing data analysis by following statistical procedures. Figure 1 describes how the variables of financial self efficacy, and social economic status influence the students financial behavior in accounting department.

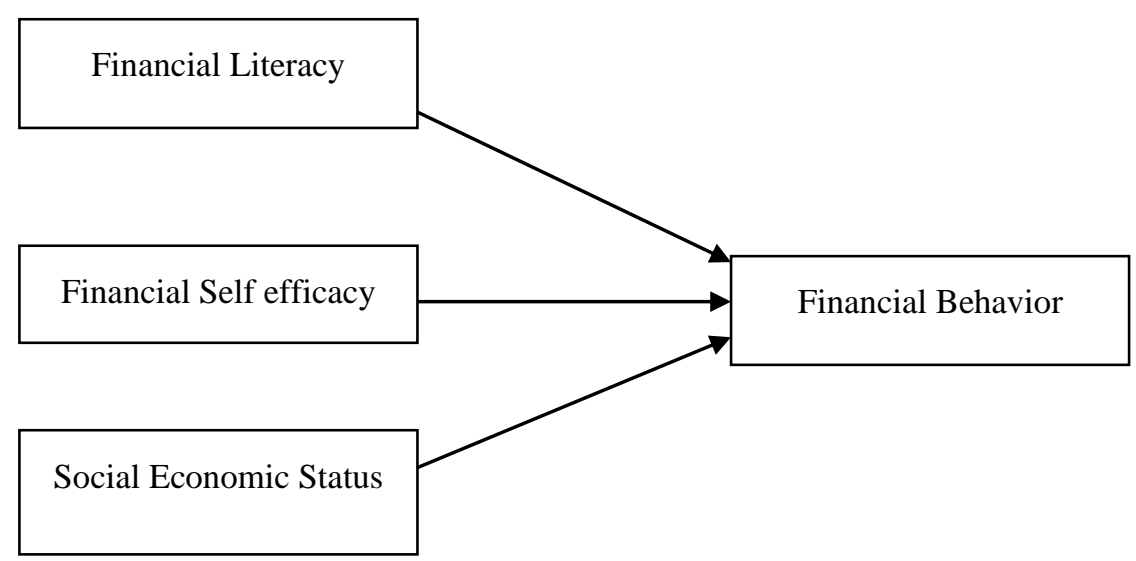

Figure 1. Research framework

\subsection{Population and Sample}

The population in this study was all students of accounting departments in Bali province in the fourth and sixth semesters in the academic year 2017/2018. The selection of this population was based on the consideration that students who were selected as respondents were those who had taken courses relevant to financial literacy, i.e., introduction to accounting, budgeting, financial management, investment and capital market. The sampling technique used was the multi stage random sampling. Multistage random sampling is a sampling technique which is done step by step from a larger population element with exact characteristics to the pulation element which is smaller innumber. This technique belongs to probability sampling, that is, the sampling technique that gives equal chance or probability to individuals in the population to be selected as sample. Thus, this technique is the only approach which can be done to geta representative sample, and making it possible for the researcher to predict to what extent the finding obtained based on the sampling will look like the actual condition in the population (Dantes, 2012). The sample adequacy was based on Herry King's Nomogram Table (Sugiyono, 2007) based on the sampling technique aboe, the sample size in this study was 518 respondents.

\subsection{Technique of Data Collection}

Data collection methods used in this study were test and questionnaire.Test is an instrument for collecting data about student's learning achievement. Thus a test administrator wants to knowthe testees' correct and wrong answers.In addition to the use of a test, in this studydata were collected through a questionnaire. Questionnaire is intended to collect data about financial behaviors, financial self efficacy, and parents' social economiic status. In this study, test and questionnaire were givento the respondents.

\subsection{Technique of Analyzing Data}

The data collected through the questionnaire were analyzed using descriptive analysis and multiple regressioin analysis. Descriptive statistics gives a picture about the level of financial literacy, financial self efficacy, social economic status, and financial behavior which can be seen in terms of mean, standard deviation, maximal and minimal scores. The next analysis was multiple regression analysis used to finding the effect of financial literacy, financial self effficacy, and social economic status on the financial behavior of the students of accounting. Before hypothesis testing, requirements were tested, i.e, normality testing, linearity testing, heterocedastisity testing and multicolinearity testing. 


\section{Results and Discussion}

\subsection{Requirements Analysis}

The results of requirement testing showed that normality testing through Kolmogorov-Smirnove (K-S) was at 1.307 and significant at $0.066>005$ so that it can be concluded that the data in this study had a normal distribution. Then, linearity testing was done by looking at ANOVA table. Based on the testing done it was found that F-Linearity value at sig $<0.05$ for all the independent variables so that it can be concluded that the regression equation in this study was linear. To test the multicolinearity, VIF value $\geq 10$ and the tolerance value $\geq 0.1$. The results of these testings proved that there was no multicolinearity phenomenon between the independent variables in the regression model. Then heteroscedastisity testing was carried out by using glejser test. Based on glejser test, all of the variables have a level of significance value $\geq 0.05$. It can be concluded that the regression model has no heteroscedastisity.

\subsection{Hypothesis Testing}

The next testing was to analyze the effect of financial literacy, financial self efficacy, and parents' social economic statusonthe students' financial behavior. The testing used multiple regression analysis whose results can be seen consecutively in Tables 1, 2 and 3

Table 1. Results of an analysis by ANOVA

\begin{tabular}{llrrrrr}
\hline Model & & Sum of Squares & df & Mean Square & F & Sig. \\
\hline 1 & Regression & 5402.919 & 3 & 1800.973 & 68.240 & $.000 \mathrm{~b}$ \\
& Residual & 13565.282 & 514 & 26.392 & & \\
& Total & 18968.201 & 517 & & &
\end{tabular}

a. Dependent Variable: financial behavior

b. Predictors: (Constant), financial literacy, financial self efficacy, social economic status

In the ANOVA part (F-test) in Table 1 aboveit is seensimultaneously that the independent variables (financial literacy, financial self efficacy, and social economic status) have a significant effect on financial behavior as shown from the value of Sig. $0,000<\alpha=0,05$. Based on the testing then it can be continued with individual test or t-test.

Tabel 2. Model Summary ${ }^{\mathrm{b}}$

\begin{tabular}{|c|c|c|c|}
\hline Model & R Square & Adjusted R Square & Std. Error of the Estimate Durbin-Watson \\
\hline 1 & $.534 \mathrm{a}$ & .281 & $\begin{array}{ll}5.137 & 2.000\end{array}$ \\
\hline \multicolumn{4}{|c|}{$\begin{array}{l}\text { a. Predictors: (Constant), financial literacy, financial self efficacy, social economic status } \\
\text { b. Dependent Variable: financial behavior }\end{array}$} \\
\hline
\end{tabular}

Based on Table 2 above, it is shown that the multitude of the determinant coeficient or the contribution of the financial literacy variable $\left(\mathrm{X}_{1}\right)$, financial self efficacy $\left(\mathrm{X}_{2}\right)$, and social economic status $\left(\mathrm{X}_{3}\right)$ on financial behavior $(\mathrm{Y})$ was $\left(R_{\text {squre }}=R_{2} x_{1} x_{2}\right)=0,285$, which means that $28,5 \%$ of the variable of financial behavior $(Y)$ can be explained by financial literacy variable $\left(\mathrm{X}_{1}\right)$. Financial self efficacy $\left(\mathrm{X}_{2}\right)$ and social economic status $\left(\mathrm{X}_{3}\right)$. The multitude of the residue coefficient $(1-28,5)=71,5$ was explained by other variables outside the model. Then, to see the multitude of the effect of financial literacy $\left(\mathrm{X}_{1}\right)$, financial self efficacy $\left(\mathrm{X}_{2}\right)$, and social economic status $\left(\mathrm{X}_{3}\right)$ on financial behavior (Y) partially, t-test was used, while to see the magnitude of the effect, Beta or Standardized Cofficient figures were used as shown inTable 6 below.

Tabel 3. Coefficients ${ }^{\mathrm{a}}$

\begin{tabular}{|c|c|c|c|c|c|c|}
\hline \multirow{2}{*}{\multicolumn{2}{|c|}{ Model }} & \multicolumn{2}{|c|}{ Unstandardized Coefficients } & \multicolumn{2}{|l|}{ Standardized Coefficients } & \multirow{3}{*}{$\begin{array}{l}\text { Sig. } \\
000\end{array}$} \\
\hline & & B & Std. Error & Beta & $\mathrm{t}$ & \\
\hline 1 & (Constant) & 16.356 & 2.217 & & 7.378 & \\
\hline & Financial literacy & .264 & .089 & .117 & 2.961 & .003 \\
\hline & Financial self efficacy & .292 & .041 & .275 & 7.109 & .000 \\
\hline & Social economic status & .488 & .052 & .363 & 9.454 & .000 \\
\hline
\end{tabular}


Based on the results oftesting in Table 3, then the regression equation of the effect of the independent variables (financial literacy, financial self efficacy, and social economic status) on the dependent variable (financial behavior) can be formulated as follows.

Financial lteracy $(Y)=16,356+0,264$ financial literacy + 0,292 financial self efficacy + 0,488 social economic status

The constant value of 16,356 indicates that if the independent variables are assumed to be constant, then the mean of the students' financial behavior level is 16,356. In addition, the regression equation above shows the effect of each independent variable on the dependent variable seen from Beta value in unstandardized coeffficients.

Based on the Coefficients Table above, it can be seen that financial literacy has a positive and significant effect on the accounting students' financial behavior. This can be seen from the valule of sig. $=0,003<0,05 ; \mathrm{t}=2.961 ; \beta=$ 0,264 , that indicates if financial literacy improves by 0,264 points. The improvement of financial literacy is the way to improve empowerment and life quality. Thus, when the students get more knowledge about the concept of money they will be able to make better financial decisions. This can be seen from their ability to manage their personal finance, to manage investments better and more regularly and have adequate insurance. This study is in line with some other studies (Vyviya, Victoria, Blue, Levon; \& Brimble, Mark, (2014); Chen and Volpe (1998); Robb and Woodyard (2011); Gutter (2008) and Susanti (2013)) who state that financial literacy has a significant effect on the students' financial behavior.

Then, from the Coefficient Table it can be concluded that financial self efficacy has also an effect on the students' financial behavior of the Accounting Department. This can be seen from the value of sig. $=0,000<0,05 ; \mathrm{t}=7.09$; $\beta=0,292$, which indicates that if financial self efficacy increases 1 point, then the students' financial behavior of the accounting department will also increase 1 point. This study was in line with other studies which show that attitude (self confidence/belief) infinancial management hasa higher mean score than self confidence in making appropriatefinancial decisions. This indicates that an individual self-efficacy influences their financial behavior in the future.Thus, self efficacyhelps the studentsto act and make a change in financial behavior toward a better direction. Other studies show that self efficacy has an effect on students' credit card loan behavior. This indicates that he students who havea high self efficacy will decrease their irrational debt seeking behavior (Danes \& Haberman, 2007; Kennedy, P. Brian, 2013). This study results show that self efficacycan be used as predictor in analyzingdebt behavior (financial behavior) in the students. Thus, in this case it can be concluded that self efficacy has an effect onfinancial behavior.

The results of the study also indicate that there is a positive and significant effect from social econmic status of the parents on the students' financial behavior. From the Coefficients Table above one can see that the value of sig. = $0,000<0,05 ; \mathrm{t}=9.454 ; \mathrm{t}=9.488$, that indicates that if parents' social economic status goes up 1 point, the students' financial behavior will go up 0,488 points. This study is in line with some other studies (Gutter, M., 2009; Carlo de Bassa, 2013) that show that parents' income has a significant effect onfinancial behavior shown by the possession of loan management, saving, and investing and making a financial plan for the future or a pension financial scheme. The results of this study also show a change toward a positive direction which means the higher the social economic status of the parents the better the students' financial behavior. Family is an external factor that includes in its social economic status, and parents' care of the children. The students who live in their stable families, have a high education, and financial sufficiency are suspected to have better financial behavior. This is in line with the results of studies that show that rationality, morality, and life style have a correlation with effectiveness and productive activity. This finding can be interpreted as follows: the higher parents' social ecomomic status, their rationality and financial morality will become better. They have better incomes, get a better financial education, and interact with a better social environment. This is what is seen indirectly by the children, who imitate their parents' financial behavior. Thus, it can be concluded that parents' social economic status has a positive and significant effect on the students' financial behavior.

\section{Conclusion}

On the basis of the results and discussion above it can be concluded that financial literacy, financial self efficacy, andparents' social economic status have direct effect on the students' financial behavior in the accounting departments. The social economic status variable has a very strong efffect on the students' financial behavior. This shows that family is the closest socialization agent able to form children's behavior. The results of this study prove that the higher the parents' social economic status the better their children's financial behavior will be. In addition, financial self efficacy, also has an effect on the students' financial behavior. Today, financial education is not the only one element that can change an individual's financial behavior toward a better direction "A major factor 
influencingconsumer behavior is the feeling of self- efficacy which is having fheconfifidence in one's ability to deal with a situation without being overwhelmed. This indicates that self confidence in one's financial abiliity that one has also influence how he or she behaves.

\section{References}

Ahmadi, A. (2007). Psikologi Sosial. Jakarta: Rineka Cipta.

Albeerdy, M.I., \& Behrooz, G. (2015). Determinants oft the Financial Literacy among College Students in Malaysia. International Journal of Business Administration, 6(3). Retrieved 2 March 2016, from https://ijba.scidupress.com

Bandura, A. (1997). Self-efficacy: Toward an Unifying Theory of Behavioral Change, Psychological Review, 84(2), 191-215. Retrieved 5 January 2016, from https://www.uky.edu/ eushe2/Bandura/ Bandura1997EP.pdf

Chen, H., \& Volpe, R.P. (1998). An Analysis of Personal Literacy Among College Stu-dents. Financial Services Review, 7(2), 107-128.https://doi.org/10.1016/S1057-0810(99)80006-7

Danes, S.M., \& Haberman, H.R. (2007). Teen Financial Knowledge, Self-Efficacy, and Behavior: A Gendered View. Financial Counseling and Planning, 18(2), 48-60. Retrieved 15 July 2015, from https://www.afcpe.org/assets/pdf/7-2866-volume-18-issue-2.pdf

Dantes, N. (2012). Metode Penelitian. Yogyakarta: PenerbitAndi.

De Bassa Scheresberg, C. (2016). Financial Literacy and Financial Behavior among Young Adult: Evidence and Implications. $\quad$ Numeracy, $6(2)$ Retrieved 10 October 2016, from https://scholarcommons.usf.edu/numeracy/vol6/iss2/art5

Dwipayani, \& Ni Made dan IK Rahyuda. (2014). Pengaruh Sikapdan Fashion Leadership Terhadap Niat Belanja Online Remaja di Kota Denpasar. Retrieved 23 November 2016, from https://ojs.unud.ac.id/index.php/Manajemen/article/view/18041/13996

Gutter, M, Zeynep, C., \& Selena G. (2015). Which Studenst are more Likely to Experience Financial Socialization Oppurtunities? Exploring the Relationship between Financial Behavior and Financial Well-Being of College Students. Retrieved 5 March 2015, from https://networksfinancialinstitute.org

Gutter, M. (2008). Financil Management Practices of College Student from States with Varying Financial Education $\begin{array}{lllll}\text { Mandates. } & \text { Retrieved } & \text { March } & \text { 2015, from }\end{array}$ https//:www.csgnet.org/ckfinder/userfiles/files/Gutter_FinMgtPracticeofColledgeStudents_Final_pdf

Heckman, S., Lim, H., \& Montalto, C. (2014). Factors Related to Financial Stress among Colledge Students. Journal of Financial Therapy, 5(1). https://doi.org/10.4148/1944-9771.1063

Henslin, M.J. (2006). Terjemahan. Sosiologidengan Pendekatan Membumi. Jakarta: Erlanga.

Herawati, N.T. (2017). Tingkat Literasi Keuangan Mahasiswa dan Faktor-Faktor yang Mempengaruhinya (Studi pada Mahasiswa Undiksha). Prosiding. Seminar Riset Inovatif ke-5, LP2M Undiksha, h.131-137

IDX. (2018). Yuk Nabung Saham. Retrieved 15 January 2018, from https://yuknabungsaham.idx.co.id/about-yns

Irin, W. (2012, October). Faktor-Faktor yang Mempengaruhi Literasi Keuangan Mahasiswa Fakultas Ekonomidan Bisnis Universitas Brawijaya. ASSET: JurnalAkuntansidanPendidikan, 1(1).

Kasmir. (2010). Pengantar Manajemen Keuangan. Jakarta: KencanaPrenada Media Grup.

Kennedy P.B. (2013). The Theory of Planned Behavior and Financial Literacy: A Predictive Model For Credit Card Debt?. Dissertations, 480. Retrieved 25 July 2016, from https://mds.marshall.edu/etd

Layli, N. (2014, September). Pengaruh Literasi Keuangan Terhadap Perilaku Mahasiswa Dalam Mengelola Keuangan. JPA UM Malang, 1(4), 277-285.

Lown, J.M. (2011). Outstanding AFCPE® Conference Paper: Development and Validation of a Financial Self-Efficacy Scale (8 February 2012). Journal of Financial Counseling and Planning, 22(2). Retrieved 10 Desember 2016, from https://ssrn.com/abstract

Lusardi, A, Mitchell, O.S., \& dan Curto, V. (2010). Financial Literacy Among the Young. The Journal of Consumer Affair, 44(2).

Pajares. (2002). Overview of social cognitive theory and of self-efficacy. Retreived 28 August, 2016, from https://www.emory.edu/EDUCATION/mfp/eff.html 
Robb, C.A., \& Woodyard, A.S. (2011). Financial Knowledge and Best Practice Behavior. Journal of Financial Counseling and Planning, 22(1), 60-70, Retrieved 15 March 2016, from https://www.afcpe.org/assets/pdf/vol22_issue_1_robbwoodyard.pdf

Sakina Rakhma, D.S. (2018). Jokowi Minta Perbankkan Sediakan Student Loan, Ini Komentar BI. Retrieved 20 March 2018, from https://ekonomi.kompas.com

Susanti. (2013). Faktor-Faktor yang Berpengaruh Terhadap Literasi keuangan dan Perilaku Keuangan Siswa SMA Negeri Surabaya. Desertasi. Tidak diterbitkan. Program Pascasarjana (PPS) Univ.Negeri Malang.

Vyviyan, V., Blue, L., \& Brimble, M. (2014). Factors that Influence Financial Capability and Effectiveness: Exploring Financial Councelors Perspectives. Australian Accounting, Business and Finance Journal, 8(4), 3-22. Retrieved 10 December 2016, from https://ro.ouw.edu.au/aabfj/vol8/iss $4 / 2$ 